\title{
Bacillus thuringiensis Combined With Fungicide Applications in the Management of Soybean Leaf Diseases
}

\author{
Mônica A. Müller ${ }^{1}$, Ana C. Klosowski ${ }^{1}$, Maristella Dalla Pria ${ }^{2}$, Sérgio M. Mazaro ${ }^{3}$ \& Louise L. May De Mio ${ }^{1}$ \\ ${ }^{1}$ Federal University of Paraná, Curitiba, PR, Brazil \\ ${ }^{2}$ State University of Ponta Grossa, Ponta Grossa, PR, Brazil \\ ${ }^{3}$ Federal Technological University of Paraná, Campus Doisvizinhos, PR, Brazil \\ Correspondence: Mônica A. Müller, Federal University of Paraná, Rua dos Funcionários 1540, 80035-050, \\ Curitiba, PR, Brazil. E-mail: mo_ang@hotmail.com
}

Received: May 12, 2019

doi:10.5539/jas.v11n13p226
Accepted: June 27, 2019 Online Published: August 15, 2019

URL: https://doi.org/10.5539/jas.v11n13p226

\begin{abstract}
Asian soybean rust (ASR) caused by Phakopsora pachyrhizi is the main soybean leaf disease in Brazil. Downy mildew (Peronospora manshurica) and powdery mildew (Microsphaera diffusa) are important soybean foliar diseases of occurrence in Paraná state. To reduce severity and yield losses caused by soybean foliar diseases, this work aimed to verify the efficacy of different application doses of the commercial product Dipel ${ }^{\circledR}$ Bacillus thuringiensis $(\mathrm{Bt})$, which is a biological insect controller, combined with number of Opera ${ }^{\circledR}$ fungicide (pyraclostrobin + epoxiconazole) intercalated applications, and to investigate the effect of the Bt Dipel ${ }^{\circledR}$ in the resistance induction of soybean. For this study, different methodologies were used, including in vitro, in vivo and field assays. The results showed that Bt Dipel ${ }^{\circledR}$ can reduce soybean foliar diseases by inducing $\beta-1,3$ glucanase enzime and phytoalexin gliceolin. The fungicide application in the experiment condition reduced yield losses.
\end{abstract}

Keywords: downy mildew, powdery mildew, Asian soybean rust, estrubilurin + triazole, resistance induction

\section{Introduction}

Soybeans are one of the main commodities cultivated on a global scale, with more than 124 million hectares cultivated. Brazil was responsible for producing approximately 119 of the 337 million tons produced worldwide in the 2017/2018 harvest, being the second largest producer in the world. In addition to expressive production, Brazil is the world's largest grain exporter (United States Department of Agriculture [USDA], 2018).

Damage to the crop reduces production and can lead to economic losses. The damage can be related to unfavorable environmental conditions, inadequate soil fertilization, pest, weeds, and disease incidence. Among the foliar diseases that occur in the soybean crop, asian soybean rust (ASR) caused by Phakopsora pachyrhizi Syd and P. Syd, is the most important in Latin America. In addition to the ASR, downy mildew (Peronospora manshurica (Naoum) Syd.) and powdery mildew (Microsphaera diffusa coke. \& Peck sin. Erysiphe diffusa) affect the crop and are of significant occurrence in the Central region of Paraná state (Roese et al., 2017; Silva et al., 2016), one of the largest producing states of Brazil.

Favorable conditions for ASR development are temperatures ranging from $21-28{ }^{\circ} \mathrm{C}$, humidity from $75-100 \%$ and minimum $6 \mathrm{~h}$ of wetness period (Nunkumar et al., 2009). Downy mildew favorable development conditions are temperatures of about $20^{\circ} \mathrm{C}$ (McKenzie \& Wyllie, 1971), high humidity (90\% or above) (Sun et al., 2017) and long wetness period $(24 \mathrm{~h})$ (Garibaldi et al., 2007). On the other hand, powdery mildew is favored by temperatures about $23{ }^{\circ} \mathrm{C}$ and $8 \mathrm{~h}$ of leaf wetness period, but it can grow in any humidity conditions (ranging from 0-100\%) (Alves et al., 2009; Brodie \& Neufeld, 1942; Roese et al., 2017).

Plants severely infected with ASR exhibit early defoliation, which compromises the formation and filling of pods, and the final weight of the grain. The earlier the defoliation occurs the smaller the grain size and consequently yield losses up to 73\% (Dalla Lana et al., 2015; Yang et al., 1991). Downy mildew and powdery mildew in high severity can reach 12 and $40 \%$ of yield losses, respectively (Igarashi et al., 2010; Silva et al., 2016). Effective control measures for these foliar diseases are needed to reduce yield losses. 
Fungicide is the main method used for controlling foliar diseases in soybean crop. The fungicides registered to control ASR belong to the chemical groups: demethylation inhibitors (DMIs), external quinone inhibitors (QoIs) and succinate dehydrogenase inhibitors (SDHIs). In addition, some of these products also control downy mildew and powdery mildew (Ministério da Agricultura, Pecuária e Abastecimento [MAPA], 2019). Fungicide efficacy has been monitored for ASR and the results demonstrate that some pathogen populations are less sensitive to fungicide action, which leads to disease control failure (Brent \& Hollomon 2007). It has been already detected resistance of $P$. pachyrhizi to the three groups of chemical fungicides in soybeans (Klosowski et al., 2016; Schmitz et al., 2014; Simões et al., 2018). Powdery mildew is mainly controlled in the USA by resistant cultivars, but in Brazil this measure is not prioritized due to the low national expression of thise disease. In view of the obstacles to efficient control by the methods currently used, it is necessary to investigate other methods such as resistance induction.

Resistance induction in plants involves the activation of latent defense mechanisms in response to biotic or abiotic agents' treatment. It works avoiding or delaying the pathogen infection or activity (Goodman et al., 1967; Oliveira et al., 2016). Resistance mechanisms may include phytoalexins accumulation and pathogenesis-related proteins such as $\beta-1,3$ glucanases, chitinases and peroxidases (Schwan-Estrada et al., 2008). Phytoalexins are defined as low molecular weight antimicrobial compounds synthesized and accumulated in plants after physical, chemical or biological stresses. Their role in resistance to pathogens is widely studied. In the case of soybean, the phytoalexin glyceolin (pterocarpanoid) is important on the interaction of this crop with phytopathogens (Burden \& Bailey, 1975; Guimarães et al., 2015). The cell wall of fungi in general has in its composition polysaccharides such as chitin and $\beta-1,3$ glucan. The expression of hydrolytic enzymes in soybean, such as chitinases and $\beta-1,3$ glucanases, which act as degrading components of the cell wall of pathogens, is considered an activation of plant defense mechanism to ASR (Adams 2004; Oliveira Almeida et al., 2012). Studies state that Bacillus sp. when applied in plants act as elicitors, inducing defense enzymes production (El-Bendary et al., 2016; Reyes-Ramírez et al., 2004).

Bacillus thuringiensis (Bt) is a gram-positive bacterium, naturally found in soil, which produces spores and protein crystals with known insecticidal action. Its morphology has been extensively studied, as well as its effects on plant defense (Melo et al., 2016). There are commercial products based on viable spores of Bt, registered for many crops, which when applied act as biological controllers, manly used for caterpillar control. Instead of using the bacteria properly, genetically modified plants that produce protein crystals called Bt crops are used as insecticidal, it was developed by moving some of the genes from the bacterium Bt into corn, cotton and recently soybean (Bravo et al., 2007).

For ASR control, application of other Bacillus sp. reduced severity in greenhouse experiment (Dorighello et al., 2015). Although there are few studies with Bt as a disease controller, it has already shown a direct effect against Erwinia carotovora (Dong et al., 2002). Lucon et al., 2010 indicated Bt as a controller of plant diseases through resistance induction, and Peng et al. (2014) studied B. subtilis in combination with fungicide applications for control of sharp eyespot of wheat. These studies demonstrated the potential of Bacillus species as a biological controller and resistance inducer to be included in soybean diseases management.

Therefore, the aim of this work was to: i) evaluate the effect of doses of Bt commercial product $\left(\right.$ Dipel $\left.{ }^{\circledR}\right)$ alone or alternated with number of fungicide Opera ${ }^{\circledR}$ (pyraclostrobin + epoxiconazole) applications in soybean leaf diseases in the field; ii) investigate in vitro and in vivo Bt Dipel ${ }^{\circledR}$ effect on resistance induction.

\section{Materials and Methods}

\subsection{Quantification of Phytoalexins in vitro}

For phytoalexin gliceolin determination, soybean seeds of the cultivar BMX Potência RR were disinfested in sodium hypochlorite $0.5 \%$ for 10 min and seeded in trays with autoclaved vermiculite. The trays with seeds was maintained in BOD (Biochemical Oxygen Demand) at $\pm 25{ }^{\circ} \mathrm{C}$ with photoperiod of 12 hours. Ten days after sowing the cotyledons were collected and placed in Petri Dishes (five cotyledons per plate). In each cotyledon a cross-section was made and $20 \mu \mathrm{L}$ of the treatments (doses of Dipel ${ }^{\circledR}$ WP $0,1,2,4,8$ and $80 \mathrm{~g} \mathrm{~L}^{-1}$ ) were placed in the section. The seeds were incubated in BOD at $25{ }^{\circ} \mathrm{C}$ in the dark for 24 hours. After this period the cotyledons were transferred to $100 \mathrm{~mL}$ erlenmeyers with $15 \mathrm{~mL}$ of distilled and autoclaved water and kept under $150 \mathrm{rpm}$ shaking for $1 \mathrm{~h}$. The cotyledons was removed, weighed and the supernatant absorbance was read in a spectrophotometer at $285 \mathrm{~nm}$ (Stangarlin et al., 2010). 


\subsection{Severity of Diseases in the Field}

Two field experiments were carried out in the Fazenda Escola Capão da Onça of the State University of Ponta Grossa, located in the city of Ponta Grossa, Paraná state $\left(25^{\circ} 05^{\prime} 27.5^{\prime \prime}\right.$ S $50^{\circ} 03^{\prime} 36.9^{\prime \prime}$ W). One experiment was carried out in season 1 (2013/2014) and another in season 2 (2015/2016), named season 1 and season 2 respectively.

The treatments consisted of doses of the commercial product Bt Dipel ${ }^{\circledR}$ WP (Sumitomo Chemical) based on Bt var. kurstaki 32.000 colony formation unit (CFU) per mg and 54\% (v/v) combined with number of applications of the fungicide Ópera ${ }^{\circledR}$ (BASF SE) formulation with active principles pyraclostrobin + epoxiconazole that was used in both seasons.

In the season 1, soybean seeds was sown in the field on November $26^{\text {th }}, 2013$, and treatments consisted on doses $0,10,20,40$ and $80 \mathrm{~g} \mathrm{~L}^{-1}$ of the commercial product Bt Dipel ${ }^{\circledR}$ combined with 0,1 or 2 applications of the fungicide Ópera ${ }^{\circledR}$ (BASF). In the season 2, soybean seeds was sown in the fieldon December 11, 2015 and treatments consisted on doses $0,1,2,4$ and $8 \mathrm{~g} \mathrm{~L}^{-1}$ of the commercial product Bt Dipel ${ }^{\circledR}$ combined with 0,1 or 2 applications of the fungicide Ópera ${ }^{\circledR}$. Fungicide was used in a dose recommended by the manufacturer on both seasons (commercial product $0.5 \mathrm{~L} \mathrm{ha}^{-1}$ ). Water volume of $200 \mathrm{~L} \mathrm{ha}^{-1}$ was applied for all treatments in both seasons.

In season 1, doses were chosen according to phytoalexin results, between 10 and $80 \mathrm{~g} \mathrm{~L}^{-1}$. High doses used in season 1 made it difficult to apply the product because the suspension was very dense. Therefore, in the season 2 doses were chose near by the recommended on Bt Dipel ${ }^{\circledR}$ label for caterpillar control in soybean, between 1.25-2.5 g L $\mathrm{g}^{-1}$ (or 250-500 $\mathrm{g} \mathrm{ha}^{-1}$ ) (Agência de Defesa Agropecuária do Paraná [ADAPAR], 2018).

The sowing of the soybean was carried out in rows, with $50 \mathrm{~cm}$ of distance between rows and $15 \mathrm{~cm}$ of distance between plants. Each plot was $3 \times 5 \mathrm{~m}$, with 6 rows $\left(3 \mathrm{~m}\right.$ wide) and 34 plants per row $(5 \mathrm{~m})$, totaling $15 \mathrm{~m}^{2}$ per plot. The four inside rows were treated and evaluated, on outside row and $50 \mathrm{~cm}$ of the beginning and the end of each plot were neither treated nor evaluated, serving as borders.

The field experiments design was completely randomized blocks consisting of a factorial with 5 levels of $\mathrm{Bt}$ Dipel ${ }^{\circledR}$ (different doses) combined with 3 levels for the fungicide (number of applications) totalizing 15 treatments. Four blocks were carried out, each block was divided into 15 plots, and each plot corresponded to one treatment. Thus, 4 replicates of each treatment were made in the experiment.

The soybean cultivar used in both field experiments was the BMX Power RR (Brasmaxx). Applications of Bt Dipel ${ }^{\circledR}$ were made weekly from the first fully developed trifoliolate leaf of soybean (phenological stage V2), until the appearance of ASR (phenological stage R1). The fungicide application was alternated with application of Bt Dipel®. It was done at the beginning of pod formation (phenological stage R3), and at the beginning of flowering, according to the number of applications of each treatment. Treatments without fungicide application were not given any treatment during fungicide application's weeks. Insecticide applications were also carried out according to the need of the crop to control pest insects.

Evaluations were carried out weekly and the severity of downy mildew, powdery mildew and ASR was quantified with the aid of a diagrammatic scale (Godoy et al., 2006; Kowata et al., 2008; Polizel \& Juliatti, 2010). In each treatment three trifolia per plants were collected, and three plants per treatment, totaling nine trifolia analyzed per treatment per week. The trifolia were collected from the lower, middle, and upper third of each plant. From these data, downy mildew, powdery mildew, and ASR disease progress curves were plotted using disease severity values obtained from non-treated leaves. The relative area under disease progression curve (rAUDPC) was calculated, in which the area below the curve of disease progression was divided by the number of days the disease symptom was observed (Cruvinel, 2005) and a regression of the severity at the critical point of the crop, which occurs in grain filling (phenological stage R5). The phenological stages of the soybean crop were determined from the system proposed by Fehr and Caviness (1977).

For both seasons the plants were harvested from the useful area of each plot and yield and weight of hundred grains was calculated in the end of the season.

\subsection{Quantification of Pathogenesis-Related Proteins in vivo}

Two experiments for pathogenesis-related (PR) protein quantification were carried out. One experiment with ASR inoculation and other with powdery mildew inoculation. An experiment for downy mildew was not carried out due to the lack of spores as source of inoculum.

For each experiment, soybean plants were grown in chambers (Conviron $\left.{ }^{\circledR}\right)$, with a temperature of $\pm 25^{\circ} \mathrm{C}$ day and $\pm 23{ }^{\circ} \mathrm{C}$ night, 12 -hour photoperiod, in 24 pots containing $3 \mathrm{~L}$ of autoclaved soil (five plants per pot). During 
the vegetative stage with unifoliolate leaves completely developed (phenological stage V1), they were treated with the doses of Bt Dipel ${ }^{\circledR} 0,1,2,4,8$ and $80 \mathrm{~g} \mathrm{~L}^{-1}$. Each treatment was applied in four pots, each pot represented a treatment repetition. Eight grams of leaves were collected over time 0, 24, 48, 96 and 192 hours after treatment (HAT).

At 48 HAT the plants were inoculated. For inoculation of the experiment with powdery mildew, diseased plants were placed between the potting treatments, as inoculum donor-plants. For the experiment with ASR, the plants were inoculated with suspension with the aid of an airbrush, containing $3 \times 10^{4}$ uredinospores $\mathrm{mL}^{-1}$ collected from the population coming from a crop of Ponta Grossa-PR season 2015/2016. The experiment was not carried out for downy mildew due to the lack of spores as source of inoculum

Two trifoliolate leaves of each plant were collected, approximately $8 \mathrm{~g}$ of foliar tissue, packed in and immediately packed in aluminum paper and placed in ultra-freezer at $-80^{\circ} \mathrm{C}$. Subsequently the samples were macerated in a mortar containing polyvinylpyrrolidone, resin, glass beads and $5 \mathrm{~mL}$ of phosphate buffer. The material was centrifuged $\left(14,000 \mathrm{~g} / 10 \mathrm{~min}\right.$ at $\left.4{ }^{\circ} \mathrm{C}\right)$ and the collected supernatant. For the quantification of total proteins, the Bradford (1976) method was used. The reading was performed in spectrophotometer at $595 \mathrm{~nm}$ absorbance.

The activities of chitinases and $\beta$-1,3-glucanase was quantified by the procedures described by Wirth and Wolf (1992) with modifications. The enzymatic activity of chitinase was assessed by the release of soluble chitin-azure oligomers from carboxymethylated chitin labeled with bright violet remazol 5R-RBV (Sigma Aldrich $\left.{ }^{\circledR}\right)$. For the spectrophotometric determination of the $\beta$-1,3-glucanase activities in the extracts, bright blue curdlan-remazol substrate (Sigma Aldrich ${ }^{\circledR}, 4 \mathrm{mg} \mathrm{mL}^{-1}$ ) was used as substrate.

The determination of the phenylalanine ammonia-lyase activity (PAL) was according to the methodology described by Kuhn (2007), through the colorimetric quantification of trans-cyanic acid released from the phenylalanine substrate.

\subsection{Data Analysis}

Field experiments were carried out in completely randomized blocks consisting of a factorial of two factors, with 5 levels of Bt Dipel ${ }^{\circledR}$ (different doses) combined with 3 levels for the fungicide (number of applications). The experiments of the two seasons were analyzed separately. Data were tabulated and submitted to analysis of variance (ANOVA). The data is presented on average or standard error. For rAUDPC, and productivity components we proceeded with the Scott-Knott test $(\mathrm{p} \leq 0.05)$, for the variable severity percentage in R5.1 soybean stage regression analysis was applied. The design used for in vivo and in vitro experiments was completely randomized and we proceeded with the Scott-Knott test $(p \leq 0.05$ and $p \leq 0.01)$. The analyzes were performed using the R (R Development Core Team, 2012) statistical software.

\section{Results}

\subsection{In vitro Experiment}

\subsubsection{Phytoalexin Gliceolin}

All doses of Bt Dipel ${ }^{\circledR}$ showed an induction effect of phytoalexin gliceolin on soybean cotyledons. Dose $80 \mathrm{~g}$ $\mathrm{L}^{-1}$ had higher production than all treatments, and doses $1,2,4$ and $8 \mathrm{~g} \mathrm{~L}^{-1}$ higher than the non-treated leaves (Figure 1). 


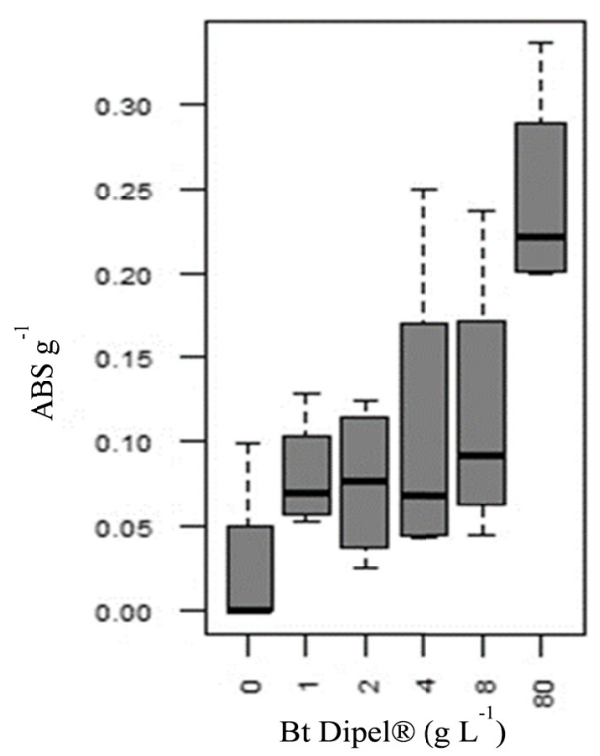

Figure 1. Boxplot of phytoalexin gliceolin measured from soybean cotyledons (Glycine max) treated with different doses of $\mathrm{Bt}$ Dipel ${ }^{\circledR}$ (Bacillus thuringiensis var. kurstaki)

\subsection{Field Experiments}

There was no interaction between the factors Bt Dipel ${ }^{\circledR}$ and fungicide application for any variable analyzed. The differences occurred between the doses of Bt Dipel ${ }^{\circledR}$ and between the number of applications of fungicides separately.

\subsubsection{Disease Progress Curves}

Analyzing the behavior of foliar diseases for non-treated leaves on season 1, at the beginning of crop, downy mildew appeared with low severity, remained stable throughout the evaluations and at the end of the cycle had no incidence in the crop. First symptoms of powdery mildew on season 1 appear at the beginning of flowering (phenological stage R1), become expressive at the beginning of pod formation (phenological stage R3) and remain until the end of the crop cycle. The appearance of ASR occurs at the end of the crop cycle reaching severity around $35 \%$. Non-treated plots no longer presented leaves for the evaluation in season 1 at the stage R7 (Figure 2). 

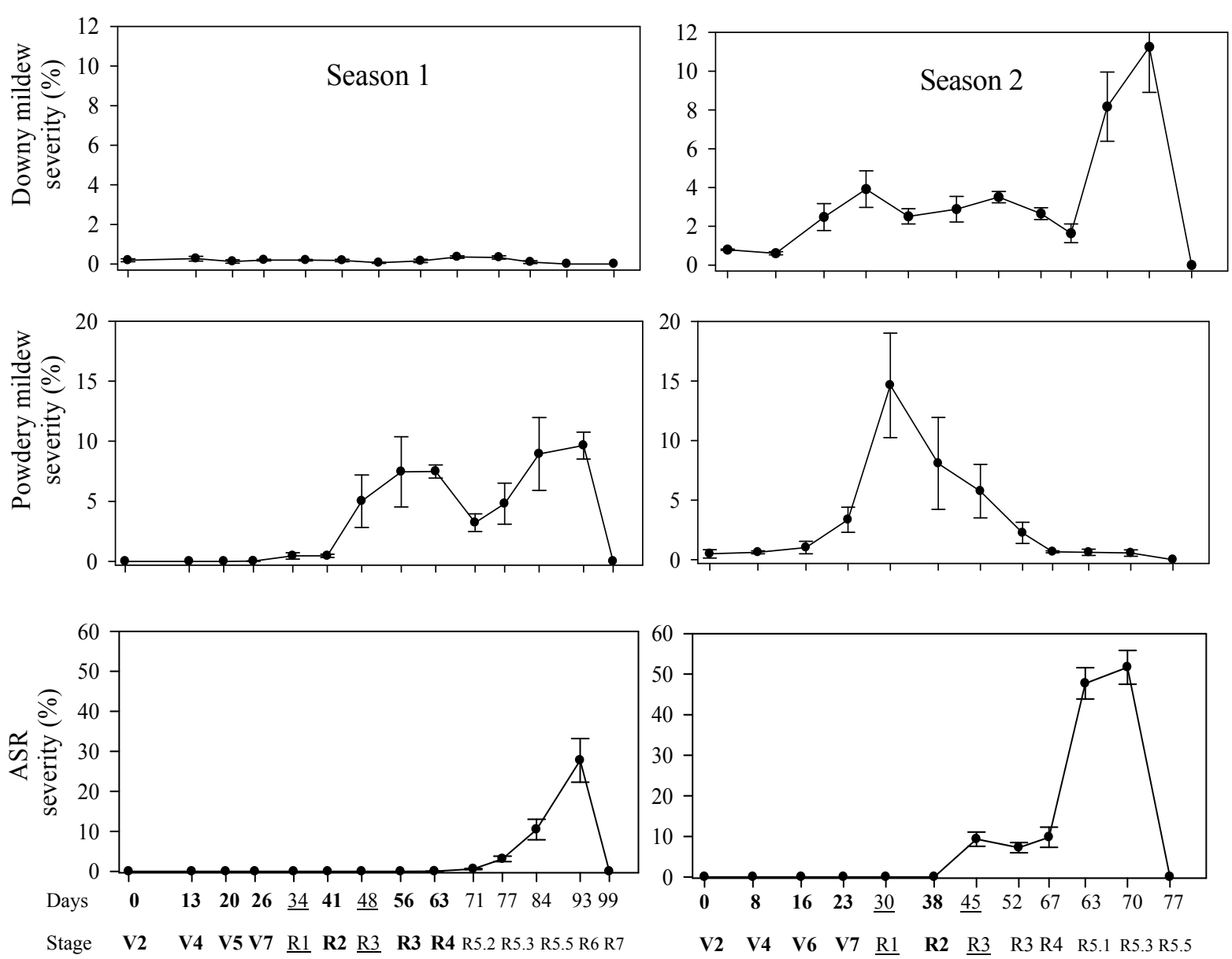

Figure 2. Progress curves of leaf diseases downy mildew (Peronospora manshurica), powdery mildew (Microsphaera diffusa) and asian soybean rust (ASR) (Phakopsora pachyrhizi) of nontreated leaves in season 1 (2013/14) and $2(2015 / 16)$ in relation to vegetative (Vn) and reproductive (Rn) phenological stages of soybean (Glycine max) and the days after the incidence. Days and stages bold or underlined means when fungicide or Bt

(Dipel) respectively were applied on treated leaves. Arrows indicate the time when fungicide was applied on treatments. Ponta Grossa/PR

In the second season, downy mildew severity was higher during all evaluations with incidence from the first evaluation. Powdery mildew also affected the culture from the first evaluation, increased the severity over time reaching the highest severity in R1 and decreased gradually until the end of the crop cycle, forming a normal distribution curve. ASR presents symptoms from R3 stage, reaching higher severity (About 45\%) in grain filling (R5 stages). Severity of ASR increased from $26 \%$ when the pod is fully developed (stage R4), to $50 \%$ on the granulation period (stage R5.3). The severity was evaluated only up to the R5.3 stage, due to the total defoliation of the plants of all treatments.

\subsection{2 rAUDPC}

The relative area under the disease progress curve (rAUDPC) for downy mildew was lower for the Bt Dipel ${ }^{\circledR}$ doses compared to the non-treated leaves in season 1 (Table 1). There were effects of doses 20 and $80 \mathrm{~g} \mathrm{~L}^{-1}$, which reduced the rAUDPC to powdery mildew. In season 2 all doses of Bt Dipel® reduced rAUDPC to ASR (Table 1). Downy mildew and powdery mildew rAUDPC were not affected in season 2 by Bt Dipel ${ }^{\circledR}$ treatments. While for ASR, all doses of season 2 reduced rAUDPC. 
Table 1. Relative area under the disease progression curve (rAUDPC) of soybean foliar diseases downy mildew (Peronospora manshurica), powdery mildew (Microsphaera diffusa) and asian soybean rust (ASR) (Phakopsora pachyrhizi), treated with doses of Bt Dipel ${ }^{\circledR}$ (Bacillus thuringiensis var. kurstaki) and alternated with number of fungicide Opera ${ }^{\circledR}$ (pyraclostrobin + epoxiconazole) applied in field trials on two seasons. Ponta Grossa/PR

\begin{tabular}{|c|c|c|c|c|c|}
\hline & \multirow{2}{*}{ Bt Dipel ${ }^{\circledR}\left(\mathrm{g} \mathrm{L}^{-1}\right)$} & \multicolumn{4}{|c|}{ rAUDPC* } \\
\hline & & Downy mildew & Powdery mildew & ASR & \\
\hline \multirow{5}{*}{ Season $1(2013 / 14)$} & 0 & $1.21 \quad \mathrm{a}$ & $19.7 \quad \mathrm{a}$ & 13.3 & ns \\
\hline & 10 & $0.78 \quad b$ & 19.9 a & 12.9 & \\
\hline & 20 & $0.88 \quad b$ & $17.1 \quad b$ & 13.9 & \\
\hline & 40 & $0.75 \quad b$ & 18.3 & 12.1 & \\
\hline & 80 & $0.83 \quad b$ & 17.3 & 13.2 & \\
\hline \multirow{5}{*}{ Season $2(2015 / 16)$} & 0 & 13.6 & 17.2 & 16.0 & $\mathrm{a}$ \\
\hline & 1 & 13.3 & 13.5 & 12.2 & $\mathrm{~b}$ \\
\hline & 2 & 14.9 & 13.6 & 14.1 & $\mathrm{~b}$ \\
\hline & 4 & 13.8 & 17.7 & 13.1 & $\mathrm{~b}$ \\
\hline & 8 & 14.7 & 12.8 & 13.3 & $\mathrm{~b}$ \\
\hline \multicolumn{6}{|c|}{ Number of applications of fungicide } \\
\hline \multirow{3}{*}{ Season $1(2013 / 14)$} & 0 & $0.81 \quad$ ns & 23.4 & 14.3 & $\mathrm{a}$ \\
\hline & 1 & 0.82 & 17.0 & 13.5 & $\mathrm{~b}$ \\
\hline & 2 & 1.00 & 15.0 & 11.4 & $\mathrm{c}$ \\
\hline & 0 & 11.6 & $12.9^{\mathrm{ns}^{-}}$ & 16.5 & $\mathrm{a}$ \\
\hline \multirow[t]{2}{*}{ Season $2(2015 / 16)$} & 1 & 10.5 & 10.1 & 13.0 & $\mathrm{~b}$ \\
\hline & 2 & 10.8 & 12.4 & 11.8 & $\mathrm{~b}$ \\
\hline
\end{tabular}

Note. *Averages followed by the same letter on the column do not differ between each other by Scott-Knott test at $5 \%$ probability. ${ }^{\text {ns }}$ Non-significant.

Fungicide application reduced rAUDPC of ASR (Table 1), two applications resulted in lower rAUDPC on both seasons. For powdery mildew in season 1 there was a reduction of rAUDPC when the fungicide was applied once or twice, this was not observed in season 2.

3.2.3 Severity at Phenological Stage R5.1

At the soybean phenological stage R5.1 (Figure 3), application of Bt Dipel ${ }^{\circledR} 8 \mathrm{~g} \mathrm{~L}^{-1}$ dose presented 23\% lower ASR severity percentage than non-treated leaves. Fungicide had not significantly difference at this stage.

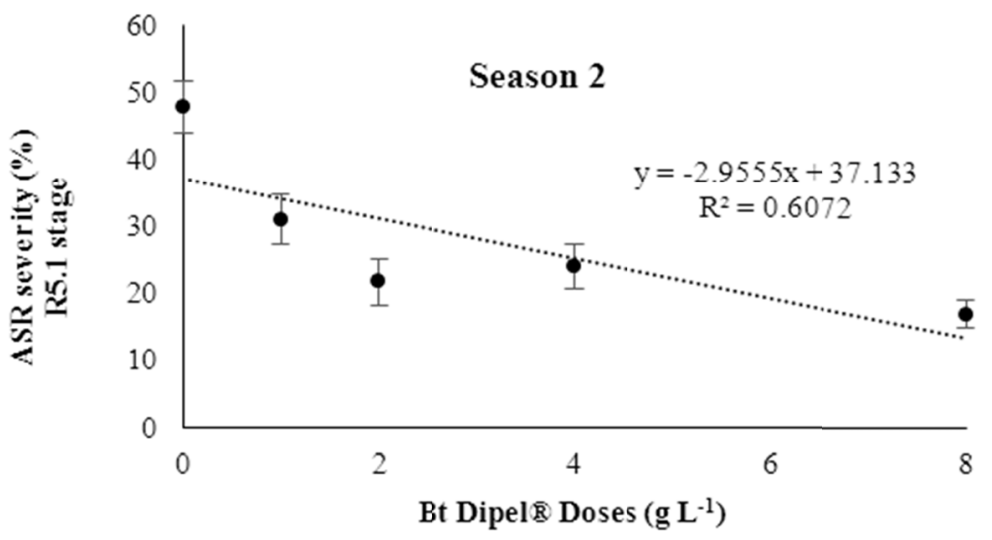

Figure 3. Regression curve between Bt Dipel ${ }^{\circledR}$ doses and asian soybean rust (ASR) severity (Phakopsora pachyrhizi) on R5.1 soybean growth stage, season 2 (2015/16). Ponta Grossa/PR

\subsubsection{Productivity Components}

Bt Dipel ${ }^{\circledR}$ increased weight of one hundred seeds for all doses in season 2 (Table 2). 
Table 2. Productivity components of soybean crop (Glycine max) season $1(2013 / 14)$ and $2(2015 / 16)$ in relation to Bt Dipel ${ }^{\circledR}$ (Bacillus thuringiensis var. kurstaki) doses and number of fungicide Opera ${ }^{\circledR}$ (pyraclostrobin + epoxiconazole) applications

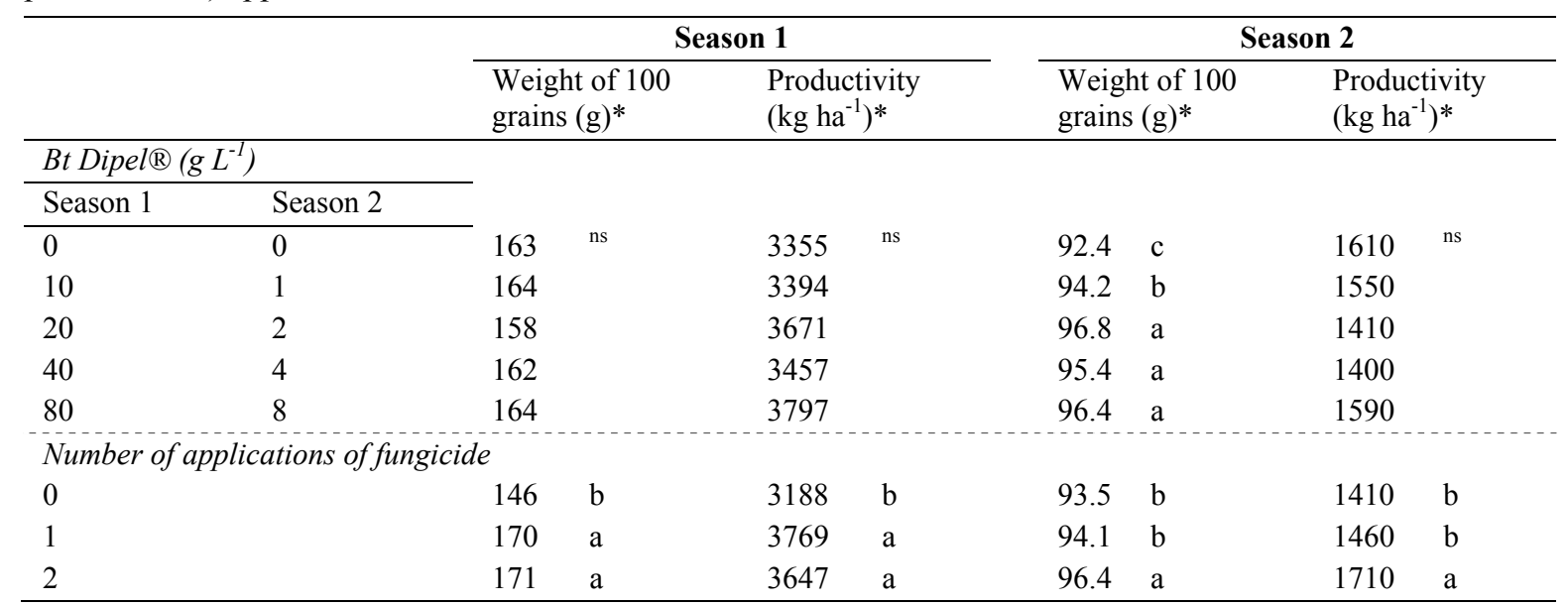

Note. *Averages followed by the same letter on the column do not differ between each other by Scott-Knott test at $5 \%$ probability. ${ }^{\text {ns }}$ Non-significant.

One or two applications of the fungicide increased the weight of hundred seeds and the productivity compared to the control for the season 1 (Table 2). For the season 2, only two fungicide applications increased the weight of one hundred seeds and yield.

\subsubsection{In vivo Experiments}

\subsubsection{Activity of hydrolytic enzimes on soybean}

$\beta-1,3$ glucanases activity on leaves were higher at the highest dose $\left(80 \mathrm{~g} \mathrm{~L}^{-1}\right)$ of Bt Dipel® for powdery mildew and for ASR (Table 3). This effect was observed 48 and 96 HAT for ASR and at 24 HAT for powdery mildew Dose of $2 \mathrm{~g} \mathrm{~L}^{-1}$ of $\mathrm{Bt}$ Dipel ${ }^{\circledR}$ behaved statistically similarly to the higher dose of Bt Dipel ${ }^{\circledR}$ for powdery mildew. 
Table 3. Activity of the hydrolytic enzymes $\beta-1,3$ glucanases and chitinase at different hours after treatment (HAT) in relation to application of different doses of Bt Dipel ${ }^{\circledR}$ (Bacillus thuringiensis var. kurstaki) on soybean leaves, inoculated with powdery mildew (Microsphaera diffusa) and asian soybean rust (ASR) (Phakopsora pachyrhizi)

\begin{tabular}{|c|c|c|c|c|c|c|c|c|}
\hline \multirow{2}{*}{ Doses of Bt Dipel ${ }^{\circledR}\left(\mathrm{g} \mathrm{L}^{-1}\right)$} & \multicolumn{8}{|c|}{ Powdery mildew } \\
\hline & \multicolumn{2}{|c|}{24 HAT* } & \multicolumn{2}{|c|}{48 HAT** } & \multicolumn{2}{|c|}{96 HAT } & \multicolumn{2}{|c|}{192 HAT } \\
\hline \multicolumn{9}{|c|}{$\beta-1,3$ glucanases $U$. E. $/ \mathrm{min} / \mathrm{mg}$ protein } \\
\hline Test & 0.0045 & $\mathrm{~b}$ & 0.0089 & ns & 0.0091 & ns & 0.0093 & ns \\
\hline Dose 1 & 0.0050 & $\mathrm{~b}$ & 0.0074 & & 0.0069 & & 0.0077 & \\
\hline Dose 2 & 0.0088 & a & 0.0080 & & 0.0072 & & 0.0097 & \\
\hline Dose4 & 0.0058 & $\mathrm{~b}$ & 0.0065 & & 0.0060 & & 0.0069 & \\
\hline Dose 8 & 0.0065 & $\mathrm{~b}$ & 0.0052 & & 0.0070 & & 0.0093 & \\
\hline Dose 80 & 0.0104 & a & 0.0115 & & 0.0085 & & 0.0117 & \\
\hline \multicolumn{9}{|l|}{ Chitinases U.E. $m g$ protein ${ }^{-1}$} \\
\hline Test & 0.59 & ns & 0.83 & $\mathrm{a}$ & 0.52 & ns & 0.71 & ns \\
\hline Dose 1 & 0.50 & & 0.90 & $\mathrm{a}$ & 0.43 & & 0.63 & \\
\hline Dose 2 & 0.60 & & 0.40 & $\mathrm{~b}$ & 0.41 & & 1.01 & \\
\hline Dose 4 & 0.50 & & 0.26 & $\mathrm{~b}$ & 0.46 & & 0.33 & \\
\hline Dose 8 & 0.49 & & 0.25 & $\mathrm{~b}$ & 0.46 & & 0.27 & \\
\hline \multirow[t]{3}{*}{ Dose 80} & 0.60 & & 0.35 & $\mathrm{~b}$ & 0.60 & & 0.45 & \\
\hline & \multicolumn{8}{|c|}{ ASR } \\
\hline & 24 HAT & & $48 \mathrm{HA}^{\top}$ & & 96 HA & & $192 \mathrm{HA}$ & \\
\hline \multicolumn{9}{|c|}{$\beta-1,3$ glucanases U.E./min/mg protein } \\
\hline Test & 0.0030 & ns & 0.0042 & $\mathrm{~b}$ & 0.0056 & $\mathrm{~b}$ & 0.0065 & ns \\
\hline Dose1 & 0.0062 & & 0.0041 & $\mathrm{~b}$ & 0.0053 & $\mathrm{~b}$ & 0.0069 & \\
\hline Dose 2 & 0.0040 & & 0.0025 & $\mathrm{~b}$ & 0.0088 & $\mathrm{~b}$ & 0.0074 & \\
\hline Dose4 & 0.0044 & & 0.0036 & $\mathrm{~b}$ & 0.0067 & $\mathrm{~b}$ & 0.0066 & \\
\hline Dose 8 & 0.0038 & & 0.0053 & $\mathrm{~b}$ & 0.0084 & $\mathrm{~b}$ & 0.0086 & \\
\hline Dose 80 & 0.0051 & & 0.0120 & a & 0.0182 & $\mathrm{a}$ & 0.0103 & \\
\hline \multicolumn{9}{|l|}{ Chitinases U.E. mg protein } \\
\hline Test & 1.23 & ns & 0.11 & ns & 0.94 & ns & 2.77 & $\mathrm{a}$ \\
\hline Dose1 & 1.28 & & 0.40 & & 0.83 & & 0.74 & $\mathrm{~b}$ \\
\hline Dose 2 & 0.72 & & 0.82 & & 0.72 & & 1.36 & $\mathrm{~b}$ \\
\hline Dose 4 & 0.51 & & 0.38 & & 0.92 & & 1.21 & $\mathrm{~b}$ \\
\hline Dose 8 & 1.26 & & 0.82 & & 0.97 & & 1.52 & $\mathrm{~b}$ \\
\hline Dose 80 & 1.19 & & 0.77 & & 1.18 & & 1.27 & $\mathrm{~b}$ \\
\hline
\end{tabular}

Note. *Averages followed by the same letter on the column do not differ between each other by Scott-Knott test at $5 \%$ probability. ${ }^{* *}$ Averages followed by the same letter on the column do not differ between each other by Scott-Knott test at $1 \%$ probability. ${ }^{\text {ns }}$ Non-significant.

For both powdery mildew and ASR, the expression of the chitinase enzyme was higher for the control than for the Bt Dipel ${ }^{\circledR}$ doses, except for the lowest dose that did not differ from the control (Table 3). While for powdery mildew this difference occurred 48 HAT, for ASR it occurred at 192 HAT.

For the FAL activity, the treatments did not differ statistically among themselves.

\section{Discussion}

This is the first study involving B. thuringiensis on soybean foliar diseases control. In this work, commercial product $B t$ Dipel ${ }^{\circledR}$ based on $B$. thuringiensis, which is naturally found in the rhizosphere, has shown a resistance inducing effect. This effect may have contributed to reduce leaf diseases severity of soybean in field conditions. Although promising results to control disease has been shown, Bt Dipel ${ }^{\circledR}$ should not be used in substitution of fungicides because productivity was not increased with Bt Dipel ${ }^{\circledR}$ doses application. An additional effect of controlling diseases may happen when recommended this product for insecticidal purposes.

There was no interaction between the treatments, which means that Bt Dipel ${ }^{\circledR}$ did not influence the fungicide and vice versa for all field variables analyzed. The reduction of the efficacy of the fungicide, observed in the 
second season, may be related to factors such as the timing of the application, environmental conditions or even fungicide resistance.

The severity of the diseases reached higher percentages in the 2015/16 season compared to the 2013/14 season due to late sowing in the 2015/16 season, which resulted in higher inoculum pressure from other areas. Also, the climatic conditions were more favorable to the occurrence of diseases. In the season 2013/14, the diseases had similar behavior to those found in other studies, in which powdery and downy mildew affects the vegetative stage (V1 to Vn) and grain filling stage (R5) but with a pronounced increase until the end of the crop cycle, and ASR begins only at the end of the cycle with explosive behavior (Barros, 2011; Silva et al., 2011). In the 2015/16 season, the increase of downy mildew and the reduction of powdery mildew at the end of the cycle was probably due to the climatic conditions. Data collected at the meteorological station, belonging to BASF S/A, in the same municipality the field experiments (Ponta Grossa-PR), showed that there was half of the precipitation in the 2015/16 season compared to the 2013/14 season, during the period before the R1 stage of the crop. The conditions of lower precipitation and relative humidity were only favorable to the development of powdery mildew, not for downy mildew, which explains the opposite behavior between these diseases in the 2015/16 season (Alves et al., 2009; Garibaldi et al., 2007; Sun et al., 2017). ASR had a previous onset in the 2015/16 season compared to the 2013/14 season due to high inoculum pressure from areas with early or regular sowing and the highest precipitation in an earlier stage of the crop that accelerated development and reproduction of the fungus (Figure 1).

Downy mildew was controlled by all doses tested of Bt Dipel ${ }^{\circledR}$ in the 2013/14 season, these doses are higher than the recommended by the manufacturer to control caterpillars (MAPA, 2019). In the season 2015/16, when the doses applied were around recommended dose, no control was observed. Also, fungicide applications had no effect for downy mildew, as expected since the fungicide used was not specific to oomycetes (Latijnhouwers et al., 2003; MAPA, 2019).

Powdery mildew was controlled by one fungicide application in the first season, but in the second season no reduction in severity of the disease was observed. There are some studies that relate a loss of efficacy of DMIs and QoIs fungicides in cucurbits (Fernández-ortuño \& Pérez-garcía, 2005) which may explain the results obtained in this work for this disease associated with the climate conditions.

Severity of ASR at the grain filling stage (R5), a critical point of crop, has high influences in weight of one hundred seeds and productivity (Barros, 2011; Dan et al., 1987; Schuch et al., 2009). Bt Dipel ${ }^{\circledR}$ treated plants had $30 \%$ less of ASR severity than non-treated leaves, at this stage of the crop, which may have reflected in weight gain of one hundred seeds and reduced rAUDPC. On the other hand, at the conditions of the experiment the productivity was not increased.

Asian soybean rust was better controlled by Bt Dipel ${ }^{\circledR}$ application than with the fungicide application, which had only $4 \%$ of reduction of disease severity in the second season. The reason for that could be related to the reports of loss of efficacy of the fungicides used to control ASR over the years (Godoy et al., 2016; Godoy et al., 2017; Godoy et al., 2018). However, in a general context the fungicide applications are efficient for the reduction of rAUDPC which reflects in less yield losses (Ribeiro \& Costa, 2000). Another point to be consider in this fungicide control failure is the timing of application, fungicide efficiency depends largely on correct timing of applications (Twizeyimana \& Hartman, 2017). Preventive applications are recommended by the Fungicide Resistance Action Committee (FRAC). In this study, in season 2015/16 one application was curative, which may also explain higher yields losses and disease severity on fungicide treatments.

Reduction in disease severity by Bt Dipel ${ }^{\circledR}$ in the field can be explained by the activation of induced resistance mechanisms, as observed on in vivo assays by phytoalexin gliceolin and pathogenesis-related protein $\beta-1,3$ glucanases induction. All Bt Dipel ${ }^{\circledR}$ doses were able to increase phytoalexin production in soybean cotyledons, and this is an important form of plant defense mechanism to prevent entry or reduce pathogen activity (Hammershimidt 1999; Stangarlin et al., 2010). In addition to the production of phytoalexins, only one application of the highest dose of Bt Dipel ${ }^{\circledR}$ activated the hydrolytic enzymes $\beta-1,3$ glucanases. Hydrolytic enzymes such as $\beta-1,3$ glucanases, which has been expressed in Bt Dipel ${ }^{\circledR}$ application, can destroy constituents of most pathogens (Adams, 2004).

Chitinases are also hydrolytic enzymes which degrades chitin, that are synthesized by plants in response of pests attack as a defense response, and the bacteria B. thuringiensis is known to produce exogenous chitinases in low levels (Hu et al., 2009; Reyes-Ramírez et al., 2004). Even if those levels were low, presence of chitinases may have been enough for recognition by plant cells with Bt Dipel ${ }^{\circledR}$ application. Since the plant recognize the presence of chitinases, it is possible that the plant generated a preference for activation of the gene coding to 
produce only the hydrolytic enzymes $\beta-1,3$ glucanases rather than having cellular machinery to produce an enzyme that was already present in the process. This may explain the reduction of chitinases activity on soybean plants that received Bt Dipel ${ }^{\circledR}$ application.

\section{Conclusion}

The commercial product Bt Dipel ${ }^{\circledR}$ doses reduce the amount of foliar diseases of the soybean crop inducing resistance by activating hydrolytic enzyme $\beta-1,3$ glucanase and phytoalexin gliceolin, but do not contribute with increased productivity. The use of the fungicide reduces the amount of biotrophic foliar diseases, preventing yield losses, but other measures of control must be integrated in the disease management.

\section{Acknowledgements}

This study was financed in part by the "Coordenação de Aperfeiçoamento de Pessoal de Nível Superior"-Brazil (CAPES)-Finance Code 001 and by the "Fundação Araucária de Apoio ao Desenvolvimento Científico e Tecnológico do Estado do Paraná"-Brazil (FA). The last author received research fellowships from National Council for Scientific and Technological Development (CNPq)/Brazil.

\section{References}

Adams, D. J. (2004). Fungal cell wall chitinases and glucanases. Microbiology, 150, 2029-2035. https://doi.org/ 10.1099/mic.0.26980-0

ADAPAR (Agência de Defesa Agropecuária do Paraná). (2018). Dipel WG. Retrieved March 15, 2019, from http://www.adapar.pr.gov.br/arquivos/File/defis/DFI/Bulas/Inseticidas/dipelwg.pdf

Alves, M. de C., Pozza, E. A., Costa, J. de C. do B., Ferreira, J. B., \& Araújo, D. V. de. (2009). Effects of temperature and leaf wetness period in powdery mildew Microsphaera diffusa Cke. \& Pk. intensity in soybean [Glycine $\max$ (L.) Merr.] cultivars. Ciênc. Agrotec., 33(Especial), 1926-1930. https://doi.org/ $10.1590 /$ S1413-70542009000700039

Barros, R. (2011). Doenças da cultura da soja. Tecnologia e Produção: Soja e Milho 2011/2012, 2.

Bravo, A., Gill, S. S., \& Soberón, M. (2007). Mode of action of Bacillus thuringiensis Cry and Cyt toxins and their potential for insect control. Toxicon: Official journal of the International Society on Toxinology, 49(4), 423-35. https://doi.org/10.1016/j.toxicon.2006.11.022

Brent, K. J., \& Hollomon, D. W. (2007). Fungicide resistance: The assessment of risk (2nd ed.). Fungicide Resistance Action Committee. Retrieved April 10, 2017, from http://www.frac.info/docs/default-source/ publications/monographs/monograph-2.pdf

Brodie, H. J., \& Neufeld, C. C. (1942). The development and structure of the conidia of Erysiphe polygoni dc. and their germination at low humidity. Canadian Journal of Research, 20(1), 41-61. https://doi.org/ $10.1139 / \mathrm{cjr} 42 \mathrm{c}-004$

Bradford, M. M. (1976). A rapid and sensitive method for the quantitation of microgram quantities of protein utilizing the principle of protein-dye binding. Analytical Biochemistry, 72, 248-254. https://doi.org/ 10.1016/0003-2697(76)90527-3

Burden, R. S., \& Bailey, J. A. (1975). Structure of the phytoalexin from soybean. Phytochemistry, 14(5-6), 1389-1390. https://doi.org/10.1016/S0031-9422(00)98633-3

Cruvinel, A. R. (2005). Epidemiologia da ferrugem asiática da soja em ambientes do estado de goiás: Efeito de fungicida e época de semeadura. Universidade Federal de Goiás, Brazil. Retrieved from https://repositorio.bc.ufg.br/tede/bitstream/tde/459/1/Adriane Reis Cruvinel.pdf

Dalla Lana, F., Ziegelmann, P. K., de N'Maia, A. H., Godoy, C. V, \& Del Ponte, E. M. (2015). Meta-Analysis of the relationship between crop yield and soybean rust severity. Phytopathology, 105(3), 307-315.

Dan, E. L., Mello, V. D. C., Wetzel, C. T., Popinigis, F., \& Zonta, É. P. (1987). Trasferência de matéria seca como método de avaliação do vigor de sementes de soja. Revista Brasileira de Sementes, 9(3), 45-49.

Dong, Y. H., Zhang, X. F., Xu, J. L., \& Zhang, L. H. (2004). Insecticidal Bacillus thuringiensis silences Erwinia carotovora virulence by a new form of microbial antagonism, signal interference. Appl Environ Microbiol, 70, 954-960. https://doi.org/10.1128/AEM.70.2.954-960.2004

Dorighello, D. V., Bettiol, W., Maia, N. B., Vilas, R. M., \& Oas De Campos Leite, B. (2015). Controlling Asian soybean rust (Phakopsora pachyrhizi) with Bacillus spp. and coffee oil. Crop Protection, 67, 59-65. https://doi.org/10.1016/j.cropro.2014.09.017 
El-Bendary, M. A., Hamed, H. A., \& Moharam, M. E. (2016). Potential of Bacillus isolates as bio-control agents against some fungal phytopathogens. Biocatalysis and Agricultural Biotechnology, 5, 173-178. https://doi.org/10.1016/j.bcab.2016.02.001

Fehr, W. R. \& Caviness, C. E. (1977). Stages of soybean development (Special Report 80, p. 11). Ames: Iowa State University of Science and Technology.

Fernández-ortuño, D., \& Pérez-garcía, A. (2005). Resistencia a fungicidas inhibidores de la biosíntesis de ergosterol en Podosphaera fusca, agente causal del oidio de las cucurbitaceas. I Reunión del Grupo Especializado Microbiología de Plantas (pp. 6-7).

Garibaldi, A., Bertetti, D., \& Gullino, M. L. (2007). Effect of leaf wetness duration and temperature on infection of downy mildew (Peronospora sp.) of basil. Journal of Plant Diseases and Protection, 114(1), 6-8. https://doi.org/10.1007/BF03356196

Godoy, C. V, Koga, L. J., \& Canteri, M. G. (2006). Diagrammatic Scale for Assessment of Soybean Rust Severity. Fitopatologia Brasileira, 31(1), 63-68. https://doi.org/10.1590/S0100-41582006000100011

Godoy, C. V, Utiamada, C. M., Meyer, M. C., Campos, H. D., Lopes, I. de O. N., \& Dias, A. R. (2018). Eficiência de fungicidas para o controle da ferrugem-asiática da soja, Phakopsora pachyrhizi, na safra 2017/2018. Circular Técnica, 138(July), 1-8.

Godoy, C. V., Seixas, C. D. S., Soares, R. M., Marcelino-Guimarães, F. C., Meyer, M. C., \& Costamilan, L. M. (2016). Asian soybean rust in Brazil: Past, present and future. Pesquisa Agropecuária Brasileira, 51(5), 407-421. https://doi.org/10.1590/S0100-204X2016000500002

Godoy, C. V., Utiamada, C. M., Meyer, M. C., Campos, H. D., Forcelini, C. A., Pimenta, C. B., et al. (2017). Eficiência de fungicidas para o controle da ferrugem-asiática da soja, Phakopsora pachyrhizi, na safra 2016/17: Resultados sumarizados dos ensaios cooperativos. Circular Técnica, 129, 1-10.

Goodman, R. N., Király, Z., \& Zaitlin, M. (1967). The Biochemistry and Physiology of Infectious Plant Disease. Van Norstrand.

Guimarães, S., Mazaro, S., Freddo, Á., \& Wagner Júnior, A. (2015). Potencial de preparados de cavalinha (Equisetum sp.) na síntese de metabólitos de defesa em cotilédones de soja (Glycine max L.) e o efeito sobre o crescimento de Rhizoctonia solani Kuhn, in vitro. Revista Brasileira de Plantas Medicinais, 17(1), 143-149. https://doi.org/10.1590/1983-084X/12 190

Hu, S. B., Liu, P., Ding, X. Z., Yan, L., \& Sun, Y. J. (2009). Efficient constitutive expression of chitinase in the mother cell of Bacillus thuringiensis and its potential to enhance the toxicity of Cry1Ac protoxin. Appl Microbiol Biothecnol, 82, 1157-1167. https://doi.org/10.1007/s00253-009-1910-2

Igarashi, S., Oliveira, G. M., Camargo, L. C. M., Falkoski Filho, J., Gardiano, C. G., \& Balan, M. G. (2010). Danos causados pela infecção de oídio em diferentes estádios fenológicos da soja. Arq. Inst. Biol., 77(2), 245-250.

Klosowski, A. C., May De Mio, L. L., Miessner, S., Rodrigues, R., \& Stammler, G. (2016). Detection of the F129L mutation in the cytochrome b gene in Phakopsora pachyrhizi. Pest Management Science, 72(6), 1211-1215. https://doi.org/10.1002/ps.4099

Kowata, L. S., May De Mio, L. L., Dalla Pria, M., \& Santos, H. A. A. do. (2008). Escala diagramática para avaliar severidade de mildio na soja. Scientia Agraria, 9(1), 105-110. https://doi.org/10.5380/ rsa.v9i1.10145

Kuhn, O. J. (2007). Indução de resistência em feijoeiro (Phaseolus vulgaris) por acibenzolar-S-metil e Bacillus cereus: Aspectos fisiológicos, bioquímicos e parâmetros de crescimento e produção (p. 140, Doctoral dissertation, Escola Superior de Agricultura Luiz de Queiroz, Universidade de São Paulo, Piracicaba).

Latijnhouwers, M., De Wit, P. J. G. M., \& Govers, F. (2003). Oomycetes and fungi: Similar weaponry to attack plants. Trends in Microbiology, 11(10), 462-469. https://doi.org/10.1016/j.tim.2003.08.002

Lucon, C. M. M., Guzzo, S. D., de Jesus, C. O., Pascholati, S., \& de Goes, A. (2010). Postharvest harpin or Bacillus thuringiensis treatments suppress citrus black spot in "Valencia" oranges. Crop Protection, 29(7), 766-772. https://doi.org/10.1016/j.cropro.2010.02.018

MAPA (Ministério da Agricultura Pecuária e Abastecimento). (2019). Agrofit-Sistemas de Agrotóxicos Fitossanitários. Retrieved from http://agrofit.agricultura.gov.br/agrofit_cons/principal_agrofit_cons 
McKenzie, J. R., \& Wyllie, T. D. (1971). The effect of temperature and lesion size on the sporulation of Peronospora manshurica. Journal of Phytopathology, 71(4), 321-326. https://doi.org/10.1111/j.1439-0434. 1971.tb03169.x

Melo, A. L. D. A., Soccol, V. T., \& Soccol, C. R. (2016). Bacillus thuringiensis: Mechanism of action, resistance, and new applications: A review. Critical Reviews in Biotechnology, 36(2), 317-326.

Nunkumar, A., Caldwell, P. M., \& Pretorius, Z. A. (2009). Development of Phakopsora pachyrhizi on soybean at controlled temperature, relative humidity and moisture periods. South African Journal of Plant and Soil, 26(4), 225-230. https://doi.org/10.1080/02571862.2009.10639959

Oliveira Almeida, H., de Oliveira Barbosa, M., Ermelinda Marques, A., Henrique Abdalla Pereira, T., Jorge Magalhães Júnior, M., \& Gusmão Tessarollo, N. (2012). Enzimas marcadoras de indução de resistência diferencialmente reguladas em soja resistente e suscetível à ferrugem-asiática-da-soja. Pesq. Agropec. Bras. 47(2), 163-172. https://doi.org/10.1590/S0100-204X2012000200003

Oliveira, M. D. M., Varanda, C. M. R., \& Félix, M. R. F. (2016). Induced resistance during the interaction pathogen $\times$ plant and the use of resistance inducers. Phytochemistry Letters, 15, 152-158. https://doi.org/ 10.1016/j.phytol.2015.12.011

Peng, D., Li, S., Chen, C., \& Zhou, M. (2014). Combined application of Bacillus subtilis NJ-18 with fungicides for control of sharp eyespot of wheat. Biological Control, 70, 28-34. https://doi.org/10.1016/j.biocontrol. 2013.11.013

Polizel, A. C., \& Juliatti, F. C. (2010). Quantificação de doenças foliares da soja por escalas diagramáticas. Enciclopédia Biosfera, 11(6), 1-9.

Reyes-Ramírez, A., Escudero-Abarca, B. I., Aguilar-Uscanga, G., Hayward-Jones, P., \& Eleazar-Corona, J. E. (2004). Antifungal activity of Bacillus thuringiensis chitinase and its potential for the biocontrol of phytopathogenic fungi in soybean seeds food microbiology and safety. Journal of Food Science, 69(5), 131-134. https://doi.org/10.1111/j.1365-2621.2004.tb10721.x

Ribeiro, A. L. de P., \& Costa, E. C. (2000). Desfolhamento em estádios de desenvolvimento da soja, cultivar BR 16, no rendimento de grãos. Ciência Rural, 30(5), 767-771. https://doi.org/10.1590/S0103-84782000000 500004

Roese, A. D., Ribeiro, P. J., \& De Mio, L. L. M. (2017). Microclimate in agrosilvopastoral system enhances powdery mildew severity compared to agropastoral and non-integrated crop. Tropical Plant Pathology, 42(5), 382-390. https://doi.org/10.1007/s40858-017-0162-4

Schmitz, H. K., Medeiros, C.-A., Craig, I. R., \& Stammler, G. (2014). Sensitivity of Phakopsora pachyrhizi towards quinone-outside-inhibitors and demethylation-inhibitors, and corresponding resistance mechanisms. Pest Management Science, 70(3), 378-388. https://doi.org/10.1002/ps.3562

Schuch, L. O. B., Kolchinsk, E. M., \& Finatto, J. A. (2009). Qualidade fisiológica da semente e desempenho de plantas isoladas em soja. Revista Brasileira de Sementes, 31(1), 144-149. https://doi.org/10.1590/ S0101-31222009000100016

Schwan-Estrada, K. R. F., Stangarlin, J. R., \& Pascholati, S. F. (2008). Mecanismos bioquímicos de defesa vegetal. In S. F. Pascholati, B. Leite, J. R. Stangarlin, \& P. Cia, (Eds.), Interação Planta Patógeno-fisiologia, Bioquímica e Biologia Molecular (pp. 227-248). Piracicaba: FEALQ.

Silva, O. C., Santos, H. A. A., Dalla Pria, M., \& May De Mio, L. L. (2016). Damage to soybean caused by downy mildew. Ciência Rural, 46(3), 389-392. https://doi.org/10.1590/0103-8478cr20150093

Silva, O. C., Santos, H. A. A., Dalla Pria, M., \& May-De Mio, L. L. (2011). Potassium phosphite for control of downy mildew of soybean. Crop Protection, 30(6), 598-604. https://doi.org/10.1016/j.cropro.2011.02.015

Simões, K., Hawlik, A., Rehfus, A., Gava, F., \& Stammler, G. (2018). First detection of a SDH variant with reduced SDHI sensitivity in Phakopsora pachyrhizi. Journal Plant Disease Protection, 125(1), 21-26. https://doi.org/10.1007/s41348-017-0117-5

Stangarlin, J. R., Schulz, D. G., Franzener, G., Assi, L., \& Kuhn, O. J. (2010). Indução de fitoalexinas em soja e sorgo por preparações de Saccharomyces boulardii. Arq. Inst. Biol., 77(1), 91-98.

Sun, S., Lian, S., Feng, S., Dong, X., Wang, C., Li, B., \& Liang, W. (2017). Effects of temperature and moisture on sporulation and infection by Pseudoperonospora cubensis. Plant Disease, 101(4), 562-567. https://doi.org/ 10.1094/PDIS-09-16-1232-RE 
Twizeyimana, M., \& Hartman, G. L. (2017). Sensitivity of Phakopsora pachyrhizi isolates to fungicides and reduction of fungal infection based on fungicide and timing of application. Plant Disease, 101(1), 121-128. https://doi.org/10.1094/PDIS-04-16-0552-RE

USDA (United States Department of Agriculture). (2018). World Agricultural Production. Retrieved from https://apps.fas.usda.gov/psdonline/circulars/production.pdf

Yang, X. B., Tschanz, A. T., Dowler, W. M., \& Wang, T. C. (1991). Development of Yield Loss Models in Relation to Reductions of Components of Soybean Infected with Phakopsora pachyrhizi. Phytopathology. https://doi.org/10.1094/Phyto-81-1420

\section{Copyrights}

Copyright for this article is retained by the author(s), with first publication rights granted to the journal.

This is an open-access article distributed under the terms and conditions of the Creative Commons Attribution license (http://creativecommons.org/licenses/by/4.0/). 